\title{
Bounty Relics: Trading in the Legacy of Myth and Mutiny
}

\author{
Adrian Young \\ Denison University
}

\section{Introduction: The thing with archives}

A pressed rose fell gently from a brittle, ageing envelope onto the table in front of me. I was in the archives of the American Museum of Natural History in New York, working through the correspondence of ornithologist James Paul Chapin, who travelled to Pitcairn Island in 1935 as part of a museum expedition to study its flora, fauna and people. After leaving, the scientist maintained a correspondence with a local named Lucy Christian. It was an exchange between the small Pacific Island and New York that spanned three decades and more than 9,000 kilometres. The envelopes bore not only letters, but also trinkets, souvenirs and tokens of affection like the dried flower that fell from Chapin's long-archived envelope. Over the years, Chapin tucked American dollars into his letters, useful to the Islanders for trade with passing ships; Lucy Christian reciprocated with painted leaves, postcards and flower pressings. Together, three decades of such exchanges produced small piles of treasure on each side of the ocean, valuable not only for their material worth but also for the connections they represent. 
Archives and institutional repositories the world over are littered with objects such as these, material things that, though scattered among the documents and folios that comprise most archival collections, fit uneasily between the flat pages of text into which they are so often found tucked. Pages of correspondence, of course, are physical objects, too - but material items like Lucy's flower comprise a super-textual archive of their own with unique stories to tell and novel perspectives to offer. ${ }^{1}$ In our case, objects such as these constitute both the substance and the remnants of a Pacific island's engagement with the wider world, a two-century history of exchanges, entanglements, friendships and exploitations. In that sense, they can elucidate the way in which the Anglophone world built its relationship with and imagination of Pacific islands. At the same time, they are also the material things with which the English-speaking world so often built its memory of the Bounty itself; treasured souvenirs that linked their owners to an increasingly distant and mythologised past. The Bounty mutiny, and Pitcairn Island with it, retains an outsized place in the Anglophone imagination - as this volume attests. Relics like Chapin's play a significant part in maintaining it.

In this essay, I explore how the Bounty mythos has built and sustained its captivating power over visitors and readers around the world, using those objects gifted, traded and stolen from Pitcairn across the last two centuries both as my archive and as the principal protagonists of my narrative. At the same time, I want to chart the way that exchanges between Islanders and 'strangers' evolved over the course of two centuries. ${ }^{2}$ From the moment of the outside world's rediscovery of Pitcairn Island in 1808, pieces of the Bounty wreck and objects crafted by the island's people changed hands, both as items of trade and tokens of affection. This chapter will follow the perambulations of these relics around the globe, locating in their paths and traces the connections from which the knowledge of a distant place was born and the memory of a mythologised moment was maintained.

1 For a rumination on the poetics of the archive, its allure, and the space between texts and things, see Helen Freshwater's 'The Allure of the Archive' (Poetics Today, vol 24, no 4, 21 Dec 2003, pp 729-58).

2 'Stranger' is not my term, but rather an autochthonous label translated loosely from a local word for outsider. The appellation used to identify Western visitors to Pacific communities is inevitably tangled in a fraught politics and poetics; Vanessa Smith, for instance, reminds us that 'friend' was, not unproblematically, among the most common terms deployed in histories of contact in her Intimate Strangers: Friendship, Exchange and Pacific Encounters (Cambridge, Cambridge University Press, 2010). Here, I use 'stranger', 'interlocutor', 'visitor' and 'tourist', and, where I can, I preserve the frame of reference from which the actors in my sources originate. 
Through the history of those objects, it will also take some measure of the effect the exchange of material culture has had not only on the place of the Pacific in the Anglophone imaginary, but on Pitcairn's people, who not only traded in Bounty relics but were sometimes transformed by that trading into Bounty relics themselves.

Gifts, objects and material culture have long been a locus of scholarly interest, especially in the Pacific. Almost a century ago, Marcel Mauss famously wrote on the debts and obligations wrought by gifts and giftgiving. ${ }^{3}$ In the years since, historians have documented the desire of sailors and scientists to collect from the Pacific islands they explored and colonised. Nicholas Thomas and scholars of his generation reminded us that the history of collection and gift exchange is inextricably linked to the politics and conditions of empire, and that the objects themselves, even if safely sealed in museum cases, retain their often violent colonial histories even now. ${ }^{4}$ Today, there remains a continuing scholarly interest in material culture. Historians of Britain and historians of science alike have taken a 'practical turn', which has privileged the exchange and circulation of ethnographic and natural historical objects. ${ }^{5}$ Moreover, an ever-growing number of authors in and beyond the history of science and exploration have treated objects as protagonists with their own varieties of agencies, histories and even subjectivities. In an early and influential essay, Arjun Appadurai perhaps put it best by arguing that 'commodities, like

3 Marcel Mauss, The Gift: The Form and Reason for Exchange in Archaic Societies, Ian Cunnison (trans), London, Cohen \& West, 1966 (1924).

4 Nicholas Thomas, Entangled Objects: Exchange, Material Culture, and Colonialism in the Pacific, Cambridge, MA, Harvard University Press, 1991; CA Gregory, Gifts and Commodities, London, Academic Press, 1982; Annie Coombes, Reinventing Africa: Museums, Material Culture, and Popular Imagination, New Haven, Yale University Press, 1997.

5 Attention to objects in science studies was pioneered by Bruno Latour and proponents of 'Actor-Network Theory'; see, for example, Bruno Latour, Science in Action: How to Follow Scientists and Engineers through Society (Cambridge, MA, Harvard University Press, 1987); and Michel Callon, 'Some Elements of a Sociology of Translation: Domestication of the Scallops and the Fishermen of St Brieuc Bay', in John Law (ed), Power, Action and Belief: A New Sociology of Knowledge? (London, Routledge \& Kegan Paul, 1986, pp 196-223). More recently, historians have become interested in the practical histories of scientific objects; see, for example, Jim Endersby, Imperial Nature: Joseph Hooker and the Practices of Victorian Science (Chicago, University of Chicago Press, 2010); Erika Rappaport, 'Imperial Possessions, Cultural Histories, and the Material Turn: Response' (Victorian Studies, vol 50, no 2, 2008, pp 289-96); Jennifer Sattaur, 'Thinking Objectively: An Overview of "Thing Theory" in Victorian Studies' (Victorian Literature and Culture, vol 40, no 1, 2012, pp 347-57); Lorraine Daston, Biographies of Scientific Objects (Chicago, University of Chicago Press, 2000); and Lorraine Daston, Things That Talk: Object Lessons from Art and Science (Cambridge, MA, Zone Books, 2007). 
persons, have social lives'. ${ }^{6}$ In the decades since, a range of authors both within and without a burgeoning school of 'thing theorists' have taken his edict to heart politically, analytically and narratively. ${ }^{7}$

This essay will build on that prolific scholarship by situating the story of intercultural exchange at a class of site that is still too often ignored in our historical narratives - a Pacific island that observers both past and present persistently deemed absolutely marginal to the main currents of empire, science and history. ${ }^{8}$ The things assembled here will, however, prove theirs to have been an imperious oversight. An active attention to objects as agents in the history of cross-cultural encounter reveals that even post-mutiny Pitcairn Island, long described as perhaps the world's most isolated inhabited spot, was in fact connected to the wider world by an elaborate network of affectively charged trades and exchanges - as so many 'remote', 'marginal' and 'insular' spaces were. What's more, if we take up Bounty relics as our principal protagonists, we can not only learn something about how material things were used as a tool by people on the edges of empire and capitalism, but at the same time understand how their material culture aided in solidifying one of the most storied moments in Britain's history and culture.

6 Arjun Appadurai, 'Introduction: Commodities and the Politics of Value', in Arjun Appadurai (ed), The Social Life of Things, Cambridge, Cambridge University Press, 1986, p 3. For Appadurai, a commodity is literally 'any thing intended for exchange (1986, p 9).

7 See, for example, Jane Bennet's Vibrant Matter: A Political Ecology of Things (Durham, Duke University Press Books, 2010), which radically expanded Appadurai's attention to the politics of things; Bill Brown's famous essay 'Thing Theory' (Critical Inquiry, vol 28, no 1, 1 Oct 2001, pp 1-22); or even Neil MacGregor's popular A History of the World in 100 Objects (New York, Viking, 2011).

8 Some scholars have begun to write new histories of colonialism and intercultural exchange through objects and collections, including Maya Jasanoffs evocatively titled Edge of Empire: Lives, Culture, and Conquest (New York, Vintage Books, 2006). Nonetheless, both within and without the history of things colonial, sites beyond the categories of nation or empire are underserved in our historical narratives - as historians of the Pacific are uniquely aware. Greg Dening made a career out of evocative histories of so-called marginal islands and liminal beaches, see especially his Islands and Beaches: Discourse on a Silent Land: Marquesas, 1774-1880 (Melbourne, Melbourne University Press, 1980). More recently, scholars building on the 'spatial turn', which was partially inaugurated by Dening himself, have written discursive histories of Pacific islands. See, for example, Beverley Haun, Inventing 'Easter Island' (Toronto, University of Toronto Press, 2008); Edward J Larson, Evolution's Workshop: God and Science on the Galapagos Islands (New York, Basic Books, 2002). 


\section{The Bounty chronometer as Bounty relic}

All of the objects that will appear in this essay are, in one form or another, Bounty relics. I do not use the word 'relic' lightly. Indeed, it is not my term at all. In the catalogue of Britain's National Maritime Museum in Greenwich, several artefacts among its most prized possessions from the Bounty and Pitcairn Island are literally labelled 'RELIC'. Let us begin, then, by picking up and examining one such relic, while handling it with the cautious respect and deference owed to sacred artefacts. The object at hand is the Bounty's chronometer, an antique timepiece small enough to fit in an open palm. It is roughly 10 centimetres across, a circle of polished brass framing a pearl-white face. Small black letters inscribe the name of its creator, Larcum Kendall, and its place of origin, London. Three dials grace its display; at one time they counted down seconds, minutes and hours, though the hands of all three lie motionless now. In those few years when sailors wound its spring and its hands still turned, however, it journeyed to and from the Pacific several times. It was through those movements and exchanges around the world and across the decades that its significance shifted - and a valuable navigational instrument transformed into a priceless relic.

The chronometer sits in leisurely retirement not far from the place it began its peripatetic life in 1771 . Produced along the lines of clockmaker John Harrison's famous seawatch, the H4 (1761), it was among the first devices of its kind. Chronometers were a revolutionary technology in the 18th century; by keeping extraordinarily accurate time at sea, they solved the famous 'longitude problem'. Navigators had long used the stars to track ships' positions precisely as they sailed north and south, but tracking positions east to west was considerably more difficult (see Teriierooiterai, Chapter 1). An unvarying clock allowed a navigator to know the time at a given reference point that, when compared to the apparent local time, would indicate the longitudinal distance a ship had travelled. Most contemporary clocks were useless for that task because ships pitched and yawed with the waves, and the rolling sea interfered with a pendulum's swing. The chronometer eliminated this problem altogether by relying on a wheel and spring for regulation. Small enough to fit in a pocket and reliable even in the most raucous seas, the new instruments revolutionised maritime navigation. 
Accordingly, early chronometers were extraordinarily rare and valuable instruments. Discounting the Bounty itself, Kendall's timepiece was by a wide margin the most expensive item entrusted to William Bligh when he set out for Tahiti in 1787. The Admiralty purchased Kendall's chronometer for a princely $£ 200$; for comparison, the Bounty itself cost $£ 1,820$. The timepiece had already guided James Cook's expedition to the Pacific and back and now it would guide the voyage of his former sailing master. Setting sail, it rounded the Cape, crossed the Indian Ocean, and lingered with the crew in Matavai Bay for five months. During the mutiny, though Bligh was given some navigation instruments to aid him and his loyal crew when they were abandoned on the ship's launch, the chronometer was too valuable and remained on board. Fletcher Christian used it to plot his path across the Pacific, and it remained in his hands through the mutineers' violent experiment in colonisation at Tubua 'i. ${ }^{\text {' }}$

After abandoning that settlement, the chronometer aided Christian in his journey to Pitcairn - though it also caused the mutineers some consternation. During his exploration of the Pacific 20 years before, without the aid of chronometer, Philip Carteret rediscovered but inaccurately charted the longitude of Pitcairn Island. Christian chose Pitcairn as the mutineers' destination after reading Carteret's account, and he was despondent on finding only empty ocean at Carteret's coordinates. Chronometer in hand, he and his crew tacked eastward along Pitcairn's recorded latitude for another 300 kilometres until they at last saw a green-shrouded rock rise from the horizon. ${ }^{10}$ After the mutineers landed on uninhabited Pitcairn, they set fire to the Bounty in the shallow waters of what would come to be called Bounty Bay - but not before taking from the ship what useful items they could, including its chronometer. The timepiece remained on Pitcairn for another three decades. Precisely who, if anyone, possessed it during that period remains uncertain. However, after a series of murders and reprisals left Christian,

9 There are dozens of accounts of the mutineers' journey but, for a meticulously empirical account, see Henry E Maude, 'In Search of a Home: From the Mutiny to Pitcairn Island (1789-1790)' (Journal of the Polynesian Society, vol 67, no 2, Jun 1958, pp 104-31). For more general accounts of the mutiny, see Sylvie Largeaud-Ortega's Introduction to this volume.

10 It is speculated that Carteret's erroneous record of Pitcairn's longitude and Christian's chronometrically informed rediscovery contributed to the mutineers' decision to settle the island, as it was thus less likely to be visited by other ships. 
his co-conspirators and their male Tahitian captives dead, the timepiece eventually came into the possession of John Adams, the settlement's last surviving mutineer. ${ }^{11}$

The chronometer remained in Adams' hands until 1808, when Pitcairn Island's post-mutiny settlement was rediscovered by the American sealers of the Topaz and their captain, Mayhew Folger. Both the Pitcairn Islanders' first interaction with strangers and the chronometer's place in it are worth recounting in some detail, as their political and material parameters set the template for generations of exchanges to come. It was a fraught and dramatic moment, with both sides unsure of each other. Would these sailors take away the last surviving member of the Bounty crew to be judged and hanged? Would this lost community of law-breakers afford the Yankees a safe landing, or would they kill to keep their haven secret? On what terms would the outside world come to understand this insular place?

After some negotiation, the Pitcairners boarded the Topaz and the Americans in turn toured the island. In their narratives of the visit, the Topaz's sailors described a peaceful community devoted to Adams, whom they recorded was a benevolent patriarch held in high esteem by the Islanders, most of whom were the children of Adams' crewmates and their Tahitian wives. ${ }^{12}$ Adams answered the Americans' questions about the mutiny, by then already slipping into legend as one of the most famous episodes in naval history. Taken by the old mutineer's account and the island's now peaceful existence, Folger and his crew gave the Pitcairners what provisions they could spare. In return, Adams handed Folger the most valuable item he owned, the Bounty's chronometer. In recognition of the extraordinary gift, Folger reciprocated with the more personal gift of a silk handkerchief. The timepiece, originally a valuable instrument of navigation, became instead an emotionally laden symbol of friendship. As such, it set the template for future interactions, in which the Pitcairners traded not only their stories of the mutiny but also their material supply of Bounty artefacts to earn their visitors' benevolence and benefaction.

11 For an account of Pitcairn's early history, see Trevor Lummis, Pitcairn Island: Life and Death in Eden (Brookfield, VT, Ashgate, 1997).

12 It is a frequently retold encounter but was first popularised in Amasa Delano, Narrative of Voyages and Travels in the Northern and Southern Hemispheres: Comprising Three Voyages Round the World; Together with a Voyage of Survey and Discovery, in the Pacific Ocean and Oriental Islands (Boston, EG House, 1817). 
For Folger, the chronometer served not only as a sentimental souvenir but as a means to authenticate his discovery of the Bounty's fate upon his return home. Folger's account of his encounter was incredible - the chronometer materially substantiated his credibility. In that sense, too, the chronometer set the mould for many Bounty relics to come; more than mere keepsakes, these souvenirs linked their owners to a distant place and served as material evidence of a story that so often seemed to occupy a more fictive register.

On Folger's return journey across the Pacific, both he and the timepiece were captured by the Spanish Navy, and the chronometer was confiscated by an enemy officer. Thus, the chronometer left his possession almost as quickly as it had entered it. During the following decades, its ownership and exchange are uncertain and unrecorded, though a British naval captain noted that it was sold in Valparaiso for three doubloons to a Spaniard named Castillo, whose family in turn sold it for 50 guineas to British naval captain Sir Thomas Herbert in $1840 .{ }^{13}$ Herbert had the timepiece rated and it served, for the last time in its career, as a navigation aid during his voyage through the Pacific, ticking evenly alongside its more modern counterparts. At some point during that return voyage, its owner wound its spring for the last time. Once back in Britain in 1843, the chronometer joined a collection of Bounty and Pitcairn relics assembled by RA Newman of the Sparrowhawk for donation to the Royal United Services Institution (RUSI), where it went on display in a museum gallery.

But first, Newman inscribed the timepiece's peripatetic history into the metal on its obverse side:

This timekeeper belonged to Captain James Cook RN and was taken by him to the Pacific in 1776. It was again taken to the Pacific by Captain Bligh in the Bounty in 1787. It was taken by the Mutineers to Pitcairn Island and was sold in 1808 by Adams to a citizen of the United States who sold it in Chile where it was purchased by Sir Thomas Herbert.

At this point, the chronometer's functionality as a navigational instrument was long superseded. Over the period of a century, the chronometer accrued successive sets of owners and significations; if it began its life as a valuable instrument of navigation and imperial ambition, it went on display half a century later as a souvenir of a distant place and as a relic

13 RA Newman, 'Note on the Bounty chronometer addressed to Sir John Barrow', The Nautical Magazine, 1840. 
of imperial history, the antique vestige of a mutiny now safely returned to its rightful place at the imperial metropole, there carefully catalogued and contained in a glass display. The chronometer moved for the last time during the 1960s, when it and many of the RUSI's collections headed down the Thames to the National Maritime Museum. It remains prominently exhibited in the museum's 'Voyagers: Britons and the Sea gallery', silently taking measure of the distance between museum-goers and an ever more removed past.

\section{Relics and reliquaries from a 'Victorian Eden'}

The chronometer is not alone; nearby in Greenwich are other objects that speak to the evolution of Pitcairn Islanders' relationship with their visitors and to the outside world's image of the mutiny that produced their settlement. These objects are not always literally inscribed by their collectors, as the chronometer was, but they are nonetheless indelibly, if invisibly, marked by their service as signifiers of a distant time and place. ${ }^{14}$ From these roving, representative objects, we can learn how their makers and collectors alike built historical memory of the Bounty and Pitcairn over time. Let us take, for example, Relic numbers 2 and 3 in the National Maritime Museum's catalogue, both of which sit on permanent display in the 'Voyagers' gallery alongside the Bounty chronometer. Relic number 2 (REL0002) is John Adams' gravestone. ${ }^{15}$ REL0003 is a small, braided lock of Adams' hair mounted inside an ornate gold oval frame. ${ }^{16}$ Why and how did these two objects, taken from the grave of a long-dead man on the other side of the world, become cherished relics in the imperial metropole?

To understand, we must read these material things themselves against both their Victorian context and the mutiny's shifting place in the Anglophone imagination. The resemblance of both objects to religious relics and their containers to reliquaries is not entirely incidental; both the lock of hair in its golden frame and the marker from Adams' tomb in its glass case testify to the religion-infused interest the Anglophone world

14 Walter Benjamin called the ineffable and original context of a work's production its 'aura', now a term of art in object studies: 'L'œuvre d'art à l'époque de sa reproduction méchanisée' (Zeitschrift für Sozialforschung, Jahrgang 5, 1936, pp 40-68).

15 Collections of the National Maritime Museum, Greenwich, United Kindom (NMM), REL0002.

16 'Pigtail', NMM/REL0003. 
came to hold in Pitcairn. Though a number of Pitcairn Islander identities have come and gone, to the Victorians they were most commonly legible as the residents of a Protestant utopia, a 'veritable Eden' on Earth. ${ }^{17}$ Early visitors to the island happily reported Adams' redemptive turn and credited the ageing ex-mutineer with the conversion of the settlement into what they described as a Christian paradise. 'They now form a happy and well-regulated society,' wrote British naval captain William Beechey after his 1825 visit in the Blossom, 'the merit of which in a great degree belongs to Adams, and tends to redeem the former errors of his life..$^{18}$ The rehabilitated mutineer was, for his part, unsubtle in performing his religiosity before his guests. During Beechey's visit, he purportedly led a church service during which the same sermon was delivered three times 'lest any part of it should be forgotten or escape attention'. ${ }^{19}$ The Islanders were orthodox in adhering to the practice of saying grace before every meal with their visitors, and proudly averred to all their guests that they never broke a vow. ${ }^{20}$ Just as crucially, during trades with passing ships, the Islanders always asked for religious texts in addition to more practical supplies.

Beechey became the first of many visiting Royal Navy captains to promote the charitable donation of supplies to Pitcairn. In his expedition account, he made several notes of the island's lack of manufactured goods. When the Pitcairners came aboard his ship for the first time, the captain recorded their amazement at its size and provisions. The sailors were 'so rich', they told him. ${ }^{21}$ Beechey solicited donations from his crew for the Islanders and subsequent ships' calls brought considerable charity. In 1841, for instance, the HMS Curacoa gave, among other sundries, 25 muskets, 25 bayonets, 20 swords, 150 fish hooks, adzes, spades, hammers, a small medicine chest, 59 religious tracts, a church prayer book, a mathematical textbook, a New Testament, a selection of hymns, publications of the American

17 I have lifted this particular phrase from the minor Rolf Boldrewood novel A Modern Buccaneer (London, MacMillan, 1894), in which the hero is seduced both by Norfolk Island and by one of its women. But the motif of Eden is rampant in the literature surrounding Pitcairn and Norfolk; Harry Shapiro was the first scholar to identify the island's 19th-century conception as a 'Victorian Eden' in a well-sourced chapter of The Heritage of the Bounty: The Story of Pitcairn through Six Generations (New York, Simon \& Schuster, 1936).

18 Frederick W Beechey, Narrative of a Voyage to the Pacific and Beering's Strait, London, Colburn \& Bentley, 1831, p 114.

19 Beechey, 1831, pp 121-22.

20 Beechey, 1831, p 102.

21 Beechey, 1831, p 97. 
tract society, and a collection of sermons for the aged. ${ }^{22}$ In return, naval visitors received not only stores of fresh fruit and vegetables but an array of historical relics. The shallowly submerged wreck of the Bounty served as a source of physical tokens of the island's famous past. Fragments of mouldering wood from the ship's hull, originally useless to the Islanders, now served as readymade curios. ${ }^{23}$ Across the 19th century, an increasing number of sailors returned home with souvenirs from Pitcairn; like the chronometer, fragments of the Bounty and locks of John Adams' hair served as tangible reminders of personal contact with both the storied ship and the Islanders who survived as the mutiny's living legacy in the Pacific.

The same sailors penned accounts of life on Pitcairn, which circulated widely in the Anglophone world. ${ }^{24}$ From them, readers received a narrative of the mutiny and settlement that was no longer framed as one of disobedience but rather of loyalty; not of violation, but of redemption. The settlement might have begun as a mutinous outpost but, thanks to its beloved patriarch, it now proudly flew the Union flag and held Anglican services. Sir John Barrow, a leading figure in the British Admiralty and a dominant force in Pacific colonisation, borrowed from the texts of his sailors and explorers, particularly those of Beechey, to pen his own history of the mutiny and Pitcairn. In it he wrote sympathetically of Adams:

What is most of all extraordinary, the very man, from whom they have received their moral and religious instruction, is one who was among the first and foremost in the mutiny, and deeply implicated in all the deplorable consequences that were the results of it. ${ }^{25}$

Other authors in turn borrowed from Barrow's history to retell the patriarch's story in their own popular and religious tracts. ${ }^{26}$ The image of a small, celebrated colony pursuing a morally and religiously exemplary

22 'August 18, 1841', Pitcairn Island Register, NMM/REC/61.

23 The Bounty hull was originally encased in copper plating, which was both sentimentally and materially valuable, but the Islanders sold most of it in 1831 to secure their passage back to Pitcairn after a failed resettlement attempt on Tahiti.

24 In addition to Beechey's, widely cited early accounts include: Delano (1817) and John A Shillibeer, A Narrative of the Briton's Voyage, to Pitcairn's Island (London, Law \& Whittaker, 1817). 25 It was in fact Barrow who dispatched Beechey to the island; see John Barrow, The Eventful History of the Mutiny and Piratical Seizure of HMS Bounty, Its Causes and Consequences (London, J Murray, 1831, pp 169-70).

26 See, The Converted Mutineer and His Bible Class: Or, John Adams and the Children of the Mutineers (Boston, Massachusetts Sabbath School Society, 1855); TB Murray, The Home of the Mutineers (Philadelphia, American Sunday-school Union, 1854); The Transformed Island: A Story of the South Seas (Philadelphia, Presbyterian Board of Publication, 1854); translated into other languages for mission work, North India Tract Society, Piṭkairn țāpü ke logon ke bayān men (Mirzapore, 1866). 
life served as a useful and bucolic counterpoint for ministers and moralisers anxious over an era of rapid industrialisation and a supposed 'crisis of faith'. ${ }^{27}$ Nathan Welby Fiske, a minister and professor at Dartmouth, wrote a biography of Adams that was meant to serve as an object lesson to young readers; it even included an imagined dialogue between a mother and her children highlighting the more morally exemplary moments in Adams' life. ${ }^{28}$ Some writers went so far as to transpose Adams' biography into an explicitly hagiographic register, positing his redemptive turn as the product of divine intervention. Anglican clergyman Thomas Boyles Murray, in his popular Pitcairn: The Island, the People, and the Pastor (1854), reported two of Adams' dreams as he underwent his conversion to Anglicanism. In one vision, a horrible being appeared and threatened to stab him with a dart. In another, he saw the future hellscape to which he, as a sinner, was surely doomed. Murray offered these two visions as the work of the Holy Spirit, 'whose merciful design it was to give [Adams] a better knowledge of himself, and a sense of the justice and goodness of God, and to bring him, an humble suppliant, to the throne of grace'. ${ }^{29}$ It was a road-to-Damascus moment befitting a secular saint.

Adams died in 1829. The archive does not record who took a lock of his hair or precisely when - indeed, we must take it on faith that the hair is his at all. It was during a visit, however, which was partly promoted by Reverend Murray, that the lock left Pitcairn. Murray, alongside other Anglican clergy, naval officers and lay admirers, set up the Pitcairn Island Fund Committee, headquartered in London. They managed donations to the island, advertised its religious success and worked to ordain the island's then spiritual leader, George Nobbs, as an Anglican pastor. When Nobbs came to London in 1852 to receive his ordination, the Royal Navy deposited ship's chaplain WH Holman as his temporary replacement. Holman lived among the Islanders for a year and, before he left, the Islanders gave him the Bounty's Book of Common Prayer and Adams' ponytail. The prayer book was a potent symbol of Pitcairn's morally

27 The extent to which a crisis of faith pervaded Victorian culture remains debated, but it was certainly a focus of period discourse; see Richard J Helmstadter \& Bernard Lightment (eds), Victorian Faith in Crisis: Essays on Continuity and Change in Nineteenth-Century Religious Belief (Stanford, Stanford University Press, 1990); David Nash, 'Reassessing the "Crisis of Faith" in the Victorian Age: Eclecticism and the Spirit of Moral Inquiry' (Journal of Victorian Culture, vol 16, no 1, 1 April 2011, pp 65-82).

28 Nathan Welby Fiske, Aleck: The Last of the Mutineers, or the History of Pitcairn's Island, 3rd edn, Philadelphia, EC Biddle, 1845, pp 133-38.

29 Thomas Boyles Murray, Pitcairn: The Island, the People, and the Pastor, London, Society for Promoting Christian Knowledge, 1854, p 112. 
infused history and religious identity and a powerful gift. As the personal relic of the island's most revered founder, the lock of hair, too, was an emotionally charged present. In Victorian society, hair was a celebrated mode of memorialisation and remembrance as a tangible connection with the departed. In the case of more famous figures, personal relics built on that tradition of personal memorialisation by positioning corporeal fragments like hair as didactically charged reminders of sanctified lives or sacred pasts. ${ }^{30}$

No archive records when, exactly, Adams' gravestone left Pitcairn, but it is likely that a sailor on the Portland took it during the same visit that either deposited or retrieved Holman.

After they arrived in London with chaplain Holman, Adams' relics went on display at the Royal United Services Institution, where they remained for a century. In their new context, Adams' artefacts made clear the Bounty mutineers' rehabilitation in the British national mythos. The Bounty's Book of Common Prayer was reunited with the Bounty chronometer in a display of cherished national artefacts. Adams' ponytail, now ensconced in a gilded case, sat in the same museum as a lock of Lord Nelson's hair. Adams' gravestone sat in the same gallery as the Victory's flag. The last mutineer's religious, corporeal and funerary relics were now the vital keepsakes of British national memory, artefacts of a celebrated moment in imperial history. Adams' Anglican turn rendered Pitcairn a site synonymous not only with treason but also, ironically, with loyalty. One 19th-century visitor, surveying the Bounty relics alongside the RUSI's other collections, wrote that the museum was 'well calculated to render the patriotic Briton proud of his country' - a remarkable achievement for the relics of a man whose co-conspirators were hanged for treason. ${ }^{31}$ Today, the relics continue to serve a similar narrative purpose, housed alongside other patriotic relics in the heart of the National Maritime Museum.

30 Deborah Lutz, 'The Dead Still Among Us: Victorian Secular Relics, Hair Jewelry, and Death Culture', Victorian Literature and Culture, vol 39, no 1, Mar 2011, pp 127-42; Christiane Holm, 'Sentimental Cuts: Eighteenth-Century Mourning Jewelry with Hair', Eighteenth-Century Studies, vol 38, no 1, 2004, pp 139-43; Daisy Hay, 'Hair in the Disraeli Papers: A Victorian Harvest', Journal of Victorian Culture, vol 19, no 3, 3 July 2014, pp 332-45; Adriana Craciun, 'The Franklin Relics in the Arctic Archive', Victorian Literature and Culture, vol 42, no 1 Mar 2014, pp 1-31.

31 The Collector, vol 6, no 15, 1 June 1895, p 249; also published as 'Relics of the Past in London', The Nation, vol 60, no 1558, 9 May 1895, pp 357-58. 
Adams' hair, prayer book and gravestone are only a small sample of the thousands of relics to travel the globe in the possession of sailors. Relics, like souvenirs, cut across geographic and temporal boundaries; though removed from their original sites and contexts, they nonetheless transcended time and space to connect their collectors and viewers with the places they remember or imagined. ${ }^{32}$ As such, they served as distant ambassadors for Pitcairn, drawing the attentions of those who held them toward the distant island and the mutiny that founded it. That interest persisted multi-generationally. As heirlooms, Bounty relics were handed down through families and guarded as special treasures. In 1853, the HMS Virago's surgeon obtained a small box supposedly made from the wood of John Adams' bed stand and metal from the Bounty. It stayed in his family for the rest of the century; in 1902, the surgeon's son could boast in London's Daily Mail that the family had preserved a relic given to them by that interesting island so long ago. ${ }^{33}$ In 1837, a sailor aboard the HMS Acteon purchased the Bounty's copy of William Buchan's Domestic Medicine. Fifty years later, his son placed the book in a gilded outer binding, along with a signed note from his father that testified that the book was in the possession of Fletcher Christian one of the mutineers until the time of his death'. ${ }^{34}$ New meanings and inscriptions accreted on these objects as they changed hands and were passed down through generations, evolving from utilitarian things to affect-laden historical relics. But these objects also literally accrued new inscriptions and framings - a golden binding, a note of provenance, a list of owners and ancillary archives of their own.

\section{Pitcairn's moral economy}

What of the people who first produced and gifted Victorian Bounty relics, the Pitcairn Islanders themselves? Most textual accounts of the island's early history were written by strangers and are squarely written from an outsider's perspective. The archive of Pitcairn's earliest local texts is small;

32 The materiality of souvenirs is a growing locus of tourism research; see Nigel Morgan \& Annette Pritchard, 'On Souvenirs and Metonymy Narratives of Memory, Metaphor and Materiality' (Tourist Studies, vol 5, no 1, 1 Apr 2005, pp 29-53); Michael Hitchcock \& Ken Teague, Souvenirs: The Material Culture of Tourism (Aldershot, Ashgate, 2000); Kristen Swanson \& Dallen J Timothy, 'Souvenirs: Icons of Meaning, Commercialization and Commoditization' (Tourism Management, vol 33, no 3, June 2012, pp 489-99).

33 Letter from William Ross, 4 Aug 1902, NMM/BGY/R/2/3.

34 William Buchan, Domestic Medicine: Or, A Treatise on the Prevention and Cure of Diseases by Simple Medicines (London, W Strahan \& T Cadell, 1774), in the collection of the Caird Library, National Maritime Museum, 613.094 BUC. 
one of the island's only early autochthonous records is its Register Book a volume of births, deaths, marriages, weather and ships' visits. Like many of Pitcairn's early relics, the first register is no longer on the island. It left Pitcairn with its owner, Pastor Nobbs, during his journey to London in 1852, but was damaged by sea spray during a rough transfer by boat from the island to the Portland. Forced to start a new volume, Nobbs gave the old, saltwater-soaked book to Reverend Murray, who used it in writing his history of the island..$^{35}$

Not only was the book a material gift, but its entries spoke to the motivations and concerns that framed Pitcairn's early exchanges with outsiders. The volume consisted mostly of notations of births, marriages and deaths. It also contained, however, a long record of ships and captains who visited Pitcairn, and many of those entries were signed by the visiting captains themselves, often with a flourish and a personal note. Each one was the record of an encounter between Pitcairn Island and an outside crew. From them, the Islanders could learn what mattered most to their guests; by the same token, we can learn from them something of the motivations that informed the island's exchanges. In 1852, Captain George Mathersby signed his name to the register and wrote:

having spent two days ashore on this most interesting Island I cannot but express the pleasure it has afforded myself as well as all the officers of the Daedelus to have visited it. I have never before had the privilege of witnessing such an example of piety with every Christian virtue attached to it. ${ }^{36}$

The Islanders also recorded their own experiences in the Register and many listed the material goods that they received from passing vessels. The register's account of the 1852 visit by the Portland's crew concludes, 'It is beyond our powers sufficiently to thank them. Among the many useful articles they left us, $[s i c]$ is a bull and a cow for which we have long wished'. ${ }^{37}$ Describing the HMS Sparrowhawk's 1839 visit, the Register records, 'In the afternoon the children of the school were examined and received the approbation of our respected visitors; Captain Stephens afterward divided a valuable present among the inhabitants' ${ }^{38}$

35 That copy of the register is in the archives of the National Maritime Museum's Caird Library, where it is still accruing and building the interest of those who read it. 'July, 1854', Pitcairn Island Register, NMM/REC/61.

36 Captain Mathersby, 'Jan 29, 1852', Pitcairn Island Register, NMM/REC/61.

37 'August 11, 1852', Pitcairn Island Register, NMM/REC/61.

38 'November 8, 1839', Pitcairn Island Register, NMM/REC/61. 
For Pitcairn, each exchange with outsiders was a profound opportunity; ships presented a magnificent and unrivalled bounty of material goods for the small island. But each visit was also a judgement. Had the Islanders lived up to their moral reputation? Were they as 'simple' and 'pious' as described?

Some visitors, aware of the dynamic at hand, fretted over the possibility of artifice in the Islanders' interactions with outsiders. In 1841, the medical officer on the Curacoa reported that the Pitcairners were 'anxious to conceal the facts' of their private disagreements: 'believing that it was only the character of their being a virtuous and innocent family which made the English Government, as well as the English people, take such an interest in their welfare and happenings. ${ }^{39}$ Holman certainly left the Islanders with that impression. A sailor on the Portland recorded one of his sermons to the Islanders: the chaplain reminded his congregants 'that the good conduct of the Islanders had made them respected' to the outside world. ${ }^{40}$ The gifts of Adams' prayer book and ponytail served as material assurances that the island, far from tainted by its founding as a mutineer's hideaway, remained a redeemed, patriotic and Protestant utopia. Inside its gilded reliquary and locked in a glass museum display, they continued to do much the same in London a century later.

\section{Pitcairn Islanders and their bodies as relics}

Though many Bounty relics came from the wreck of the ship itself, original Bounty relics did not constitute an unlimited resource. In their place, it was not uncommon for the Islanders' bodies to produce the sentimental objects necessary for trade. ${ }^{41}$ The Islanders were, after all, often conceived of by their visitors as the living relics of the mutiny. Pitcairners' hair was an especially common token of affection; Adams' ponytail was not the only lock from Pitcairn brought to Britain. In 1855,

39 William Gunn, Medical Journal of the HMS Curacoa (1841), The National Archives, London (NA), ADM/101/95/4A.

40 As quoted from personal correspondence in Diana Belcher's The Mutineers of the Bounty and their Descendants in Pitcairn and Norfolk Islands (New York, Harper Brothers, 1871, p 221). Belcher was a descendant of Beechey.

41 The metonymic power of capitalism to reify social relations and reduce people to objects or to allow objects to stand in for people was described early and famously by Karl Marx and later analysed in depth by Georg Lukács; see, Karl Marx, Capital, vol 1, especially 'Section 4: The Fetishism of Commodities and the Secret Thereof' (1867), and Georg Lukács, 'Reification and the Consciousness of the Proletariat', in History and Class Consciousness (1923). 
George Nobbs wrote in his diary that 'the mania for making presents [is] still raging and the cutting off locks of hair is practiced on every head, to be woven in bracelets. ${ }^{42}$ Most of these went to visiting sailors. Captain James Wood, who called in 1849 on the Pandora, wrote that many of his crew 'contrived to establish flirtations, which, though short enough, brought long faces and wet eyes at parting, and many were the locks of hair, etc., which changed owners' ${ }^{43}$ Hair was, however, subject to fluid meanings and interpretations. George Inskip, a sailor on HMS Comet in 1831, asked the island's women if he could take cuttings of their hair. They sat down in a row and let the sailor work through their tresses with scissors. If the women thought this act was a token of romantic affection, they were not necessarily wrong, but were certainly only half right. Inskip kept the locks for decades afterward, remarking on how they 'show the contrast between the colour of the Tahitian and that of the mixed English breed'. ${ }^{44}$ His was only the beginning of a long interest in the Islanders' bodies not only as historically or affectively laden symbols, but as signs of racial mixture and difference.

During the latter half of the 19th century, perceptions of the island and its uses as an exemplary space began to shift. Missionaries and sailors still penned glowing accounts of the island's pious morality, but another set of outsiders began to imagine Pitcairn and its people as a different kind of object lesson. Scientists and intellectuals, having read the morally infused literature on the island, came to regard its isolated population as ripe for anthropological and eugenic research. In 1856, the population of Pitcairn was removed to Norfolk Island, a former prison colony thousands of miles away. In the British parliament and in the press, the move was referred to as 'The Experiment'. Would the mutineers' descendants replicate their past success, they wondered, and turn another Pacific hell into a second pacific Eden? Though the terms of that experiment were originally framed as moral and religious, British intellectuals soon imbued it with scientific potential. Naturalist Alfred Russel Wallace wrote that the island remained 'of the highest social and political interest', as 'it is so rarely that social problems can be subjected to anything like a critical experiment'. ${ }^{45}$ Much of Britain's scientific attention stemmed from the island's mixed Polynesian

42 George Nobbs, 'Tuesday, January 3rd', Register and Memorandum, Norfolk Island, 1861, transcription of microfilm copy held in the Mitchell Library, State Library of NSW, FM4/7365.

43 James Wood, 'Pitcairn Island in 1849', letter reproduced in Belcher, 1871, p 212.

44 George Hastings Inskip, 'Pitcairn's Island', NMM/MSS 76104.3, 87. Inskip's account, which in places plagiarised from that prepared by Thomas Boyles Murray, was written years after his visit.

45 Alfred Russell Wallace, "The Mutineers of the Bounty, and their Descendants in Pitcairn and Norfolk Islands, by Lady Belcher', The Academy, 1 Feb 1871, p 108. 
and British heritage and supposed isolation, which allowed them to serve as a 'natural laboratory' in anthropological debates about race mixture. Charles Darwin and members of the Ethnological Society of London, for instance, pointed to the Pitcairners' reproductive success in order to dispel the idea that mixed-race societies tended toward degeneration and infecundity, while at the same time a nascent eugenic school wondered over the Islanders' vitality and intelligence. ${ }^{46}$

Most discussions of Pitcairn in the scientific and popular press remained abstract theorisations built on the basis of travel accounts. Accordingly, on those rare occasions when Pitcairn Islanders visited Britain, they found themselves to be objects of fascination. When Russell McCoy visited London in 1881, his stay prompted considerable attention from the public and the press, a response that was due in no small part to the work of enterprising stage managers at the Royal Aquarium in Westminster who contrived to put him on display. The Aquarium was an all-purpose venue, home to stage plays, music and all manner of carnivalesque performances - including the exhibition of people from other parts of the world. ${ }^{47}$ In the case of McCoy, visitors were invited, for a small fee, to meet this 'veritable Pitcairn Islander'. An English-speaking Christian, he proved a difficult figure to exoticise. Newspapers seemed to recognise the ironic disconnect between romantic Pacific image and quotidian embodied reality. 'There will be nothing but friendly welcome for this English South Seas Islander, who comes guarded by the not ineffective talisman of his wife's wedding ring,' declared one. ${ }^{48}$ What did he think of London's modern wonders? 'His astonishment at beholding the steamengines and railway carriages was very great,' reported another newspaper. 'He was very deeply impressed. ${ }^{39}$ McCoy spent an afternoon on display before a sympathetic Anglican clergyman rescued him from the ignominy and shuffled him offstage. ${ }^{50}$

46 John Crawfurd, 'On the Supposed Infecundity of Human Hybrids or Crosses', Transactions of the Ethnological Society of London, vol 31 Jan 1865, pp 356-62; Charles Darwin, The Descent of Man and Sexual Selection in Relation to Sex, 1871, p 154; FW Farrah, 'On Hybridity', Journal of the Anthropological Society, 5 April 1864, pp 222-27.

47 'Ethnographic' exhibitions of people were commonplace entertainments in fin-de-siècle Europe and America; see Sadiah Qureshi, Peoples on Parade (Chicago, University of Chicago Press, 2011); Roslyn Poignant, Professional Savages: Captive Lives and Western Spectacle (New Haven, Yale University Press, 2004).

48 'A Pitcairn in London', Launceston Examiner, 7 July 1881, p 3.

49 'Pitcairn Island', Penny Illustrated Paper \& Illustrated Times (London), no 1034, 7 May 1881, p 300 .

50 The story was retold in Rosalind Amelia Young, Mutiny of the Bounty and Story of Pitcairn Island, 1790-1894 (Mountain View, California, Pacific Press, 1894, p 219). 
In the hands of anthropological science, however, the reification of Pitcairn Islanders into objects of fascination was far more totalising. ${ }^{51}$ Archaeologist Karen Routledge concluded her work on Rapa Nui/Easter Island in 1917 (see Molle \& Hermann, Chapter 2) and, during her voyage home, she called on Pitcairn and collected two Islanders, the brothers Charles and Edwin Young, offering to take them to Britain. ${ }^{52}$ Upon the expedition's arrival in Europe, Routledge deposited the Young brothers, along with the skeletal material she had excavated on Rapa Nui, at the Royal College of Surgeons' Hunterian Museum, an anatomical repository that remains the last resting place of thousands of human remains from around the world. There, they underwent an examination by Arthur Keith, the museum curator and one of the world's leading experts in physical anthropology and the science of race. ${ }^{53}$ Keith recognised the rare opportunity presented by the arrival of the Youngs. These Islanders and their bodies were, to him, the relics not only of mutiny but of a century-old act of miscegenation, and thus scientifically valuable. Keith examined their bodies and skulls with calipers, taking over 30 measurements of each.

Their brains, Keith decided, were smaller than those of Europeans. The anatomist also carefully measured the hue of their skin and noted 'Polynesian' and 'European' qualities in each brother's morphology. These data were read against the skeletonised body of a Tahitian man who died in London in 1816, in order to determine the results of six generations of 'racial admixture'. ${ }^{54}$ Keith pronounced that, while the brothers were physically healthy, they were, in racial terms, mentally deficient. Corporeal interest in the Islanders remade the Pitcairners' bodies into a new kind of Bounty relic. They had long served as markers of Englishness persisting unexpectedly in the remote Pacific. While earlier accounts emphasised their affinity with Britain, or at least a religious and romantic ideal of Britishness, later accounts emphasised, in racial and scientific terms, the Islanders' bodily differences. Rather than symbols of purity, the Islanders

51 Concomitant with the era's physical anthropology; see, Andrew Zimmerman, Anthropology and Antihumanism in Imperial Germany (Chicago, University of Chicago Press, 2001).

52 Katherine Pease Routledge, The Mystery of Easter Island: The Story of an Expedition (London, Hazell, Watson and Viney, 1919); see also her biography by JoAnne Van Tilburg, Among Stone Giants: The Life of Katherine Routledge and Her Remarkable Expedition to Easter Island (New York, Simon and Schuster, 2003). For more on archaeology, see Molle \& Hermann, Chapter 2.

53 Katherine Routledge, letter to Arthur Keith, 29 Aug 1916, Keith Papers, Archives of the Royal College of Surgeons, MS0018/2/1/11/5.

54 Arthur Keith, 'The Physical Characteristics of Two Pitcairn Islanders', Man, vol 17, Aug 1917, p 121-31. 
were now construed as anything but that, a hybrid people cast by a famous historical act not into paradise but rather into the interstices between racial categories. Routledge and Keith remade their skulls into relics of the Bounty crew's acts of 'racial admixture'.

Pitcairn Islanders remained the objects of scientific scrutiny for decades to come. The American anthropologist Harry Shapiro visited Norfolk Island in 1923 and Pitcairn Island in 1934 in order to take anthropometric measurements of the island's entire population. ${ }^{55} \mathrm{His}$ Bounty relics sit in the repository of the American Museum of Natural History, only a few shelves away from the pressed rose that fell from the envelope described in the opening pages of this essay. Shapiro's relics take the form of large, ruled sheets cataloguing every Islander's age, and eye and hair colour, alongside the width, length and height of their skulls. Most crucially, he recorded each Islander's genealogy, tracing each living Pitcairner's lineage back to the mutiny that begat their isolation and made them of scientific interest. ${ }^{56}$ Shapiro also took hundreds of black-and-white photographs, a pair for nearly every Pitcairn Islander alive when he visited in 1934. In each set of portraits, a posed figure stares first straight ahead and then glances to the side in profile. These photographs were not mere keepsakes, but rather a scientific record meant to serve as a standardised archive of the Islanders' bodies. Shapiro's work among the Islanders was, in a mode consistent with the period's physical anthropology, in turns deeply intimate and detached. He spent hours touching and recording their bodies, only to convert them to quantifiable data. His field notes suggest an amicable but emotionally distant relationship between scientist and subject. Nonetheless, he left the island with a small, wooden shard of the Bounty's rudder that he framed once back in New York. ${ }^{57}$

Ultimately, Shapiro used Pitcairner's bodies as evidence to intervene in the period's debates surrounding race and eugenics. He reported that anthropometry revealed them to be robust and healthy, overturning Keith's assessment and disproving the notions that either miscegenation

55 Harry L Shapiro, Descendants of the Mutineers of the Bounty, Memoirs of the Bernice P Bishop Museum, vol 1112, Honolulu, The Bishop Museum, 1929; and Harry L Shapiro, The Heritage of the Bounty: The Story of Pitcairn through Six Generations, New York, Simon \& Schuster, 1936; Warwick Anderson, 'Hybridity, Race, and Science: The Voyage of the Zaca, 1934-1935', Isis, vol 103, no 2, 1 June 2012, pp 229-53.

56 Papers of Harry Lionel Shapiro, American Museum of Natural History, New York (AMNH), Boxes $33 \& 35$.

57 'Artifacts', Shapiro Papers, AMNH/Box F. 
or Pitcairn's degree of inbreeding were biologically deleterious. His work became a key component of inter-war Anglophone race science and was cited in refutations of Nazi propaganda. ${ }^{58}$ Shapiro, however, was not the last visitor to refashion the Islanders' bodies into objects of evidence. Indeed, the notion that the Islanders and their bodies are themselves Bounty relics persists to this day. Geneticists from the United States and Australia have done studies on Norfolk Island, taking samples of the Islanders' blood and collecting genealogies. Recent work has sought to identify markers of English and Polynesian ancestry in the mutineer descendants' blood, what one paper called 'the biometry of the Bounty'. ${ }^{59}$ The material bodies of the mutineers' descendants remain, at least in the eyes of Australian and American biological science, invisibly but permanently marked by a historical act perpetrated by their forefathers.

\section{Relics as souvenirs, souvenirs as relics}

The transformation of perceptions of Pitcairn from moral paradise into eugenic dystopia in the first decades of the 20th century had severe effects on the livelihoods of the Islanders. As the 19th century gave way to the 20th, the Islanders found that their status and stories afforded them less and less benefaction from outsiders, not least the British Government. ${ }^{60}$ Reports by visitors grew increasingly pessimistic and disillusioned. A colonial administrator who visited Norfolk Island in 1910 wrote, 'of course everybody coming here says "what grand people" ... I called here one day passing in the steamer and I went to church. I said "what grand people". The next time I came here I found out what they were'. The Islanders, he claimed, had degenerated as a result of their heritage and only put on a moral act to appease their guests. Summarising the past half century since the 'experimental' transplantation of much of the population to Norfolk Island, he declared:

58 Elazar Barkan, The Retreat of Scientific Racism, Cambridge, Cambridge University Press, 1992, pp 143-48.

59 David A Mackey, Justin C Sherwin, Lisa S Kearns ... Alex W Hewitt, 'The Norfolk Island Eye Study (NIES): Rationale, Methodology and Distribution of Ocular Biometry (Biometry of the Bounty)', Twin Research and Human Genetics: The Official Journal of the International Society for Twin Studies, vol 14, no 1, Feb 2011, pp 42-52.

60 The island's conversion to Seventh-Day Adventism also resulted in a diminution of support from their Anglican allies in Britain, though it conversely brought benefaction from co-religionists in the United States. 
I do not hesitate to say that no experiment has ever failed so dismally, and that the Norfolk Islanders of today, so far from being innocent and virtuous, are as debased, as idle, as immoral or - unmoral perhaps would be a more suitable epithet - a people as exists on the face of the earth. ${ }^{61}$

In response, however, another colonial office bureaucrat urged his colleagues to restrain their outrage. The Islanders on both Pitcairn and Norfolk, he argued, lived in the aftermath of history and were forced to adapt to their unique circumstances.

We must take into consideration the fact that for a hundred years past the Community has lived on charity from passing vessels, and the Islanders have long ago learned that the romance surrounding their history, and their reputation for loyalty to the throne, as well as for simplicity and innocence and devout religious belief, have always been their assets; their stock-in-trade, in short, which leads to the good opinion of visitors and to consequent gifts ... Considering therefore, the whole history of these people, and their descent and conditions of life it is, perhaps, unjust to stigmatise as hypocrisy and deceit, the smooth face, the ingratiating manner, and the profession of religion which these poor people are, so to speak, compelled to put on in order to live. ${ }^{62}$

The Islanders, he said, were not the recipients of charity, the one-sided distribution of gifts from visitors to the objects of their benevolence. Rather, by adapting the roles into which outsiders cast them and building upon them, the Islanders participated in a reciprocal exchange.

If the 'romance surrounding their history' was the Islanders' 'stock-intrade', then its value rose considerably and unexpectedly after the 1930s. Charles Nordhoff and James Hall penned a bestselling account of the mutiny and its aftermath in three novels that were read by millions and adapted into a series of films (see Largeaud-Ortega, Chapter 4; and Jolly

61 NA/CO 537/463. It was a moral appraisal that resonated with Pitcairn Island's infamous sexual abuse trials around the turn of the millenium. For a journalistic account of the trials, see Kathy Marks, Lost Paradise: From Mutiny on the Bounty to a Modern-Day Legacy of Sexual Mayhem, the Dark Secrets of Pitcairn Island Revealed (New York, Free Press, 2009). It is an unpopular book on Pitcairn. For a broader meditation on Pitcairn and Norfolk's persistence as objects of the outside world's moral imagination, see this author's dissertation, 'Mutiny's Bounty: Pitcairn Islanders and the Making of a Natural Laboratory at the Edge of Britain's South Seas Empire' (PhD dissertation, Princeton University, 2016).

$62 \mathrm{NA} / \mathrm{FO} / 687 / 15$. 
\& Petch, Chapter 6).$^{63}$ In the years that followed, Harry Shapiro drew from his Pitcairn research to publish a popular book on the Islanders. ${ }^{64}$ Magazines like National Geographic published positive, if heavily eroticised, accounts of island life. ${ }^{65}$ This work was part of a general reestablishment of the South Pacific as a space of romanticised interest in American popular culture, a cultural shift that was concomitant with the American geopolitical ambitions in the Pacific. ${ }^{66}$ Pitcairn Island, for the last decades derided by British administrators and intellectuals as an example of moral collapse and racial miscegenation, was exotic again. The inter-war period also saw Pitcairn Island reach its peak population of roughly 230. More materially, the opening of the Panama Canal in 1914 put Pitcairn Island roughly on the route between the West and New Zealand. Consequently, freight and passenger ships bound for Wellington and Auckland began to stop at Pitcairn in unprecedented numbers. ${ }^{67}$

Passenger liners and private yachts brought with them a new class of visitor: the tourist. Sailors had long left the island with Bounty relics and trinkets in hand, but steady visits by passenger ships created a souvenir market on a much larger scale, a trade that continues to this day. The tourists' most sought-after object was a genuine Bounty artefact, which even a century-and-a-half later could be found at affordable prices. Irving Johnson, an American who visited several times on a yacht, purchased a part of the Bounty's rudder and several gudgeons in 1937. Eyeing the ship's antique vise, he offered the community a modern replacement and

63 Charles Nordhoff \& James Norman Hall, Mutiny on the Bounty, New York, Boston \& London, Back Bay Books, Little, Brown \& Company, 1932; Men against the Sea, Boston \& London, Back Bay Books, Little, Brown \& Company, 1934; and Pitcairn's Island, New York, Boston \& London, Back Bay Books, Little, Brown \& Company, 1934.

64 Shapiro, 1936.

65 Irving Johnson \& Electra Johnson, 'Westward Bound in the Yankee', National Geographic, vol 81, Jan 1942, pp 1-44; Irving Johnson \& Electra Johnson, 'The Yankee's Wander-world', National Geographic, vol 95, Jan 1949, pp 1-50; TC Roughley, 'Bounty Descendants Live on Remote Norfolk Island', National Geographic, vol 118, Oct 1960, pp 558-84; Louis Marden, 'I Found the Bones of the Bounty', National Geographic, vol 112, Dec 1957, pp 725-89.

66 Julian Go, "Racism” and Colonialism: Meanings of Difference and Ruling Practices in America's Pacific Empire', Qualitative Sociology, vol 27, no 1, Mar 2004, pp 35-58; Adria L Imada, Aloha America: Hula Circuits Through the US Empire, Durham, Duke University Press, 2012; Shelley Sang-Hee Lee \& Rick Baldoz, “A Fascinating Interracial Experiment Station”: Remapping the Orient-Occident Divide in Hawai'i', American Studies, vol 49, no 3, 2008, pp 87-109; Robert W Rydell, All the World's a Fair: Visions of Empire at American International Expositions, 1876-1916, Chicago, University of Chicago Press, 2013.

67 For a comprehensive catalogue of every ship to visit Pitcairn, see Herbert Ford's Pitcairn Port of Call (Angwin, CA, Hawser Titles, 1996). 
US $\$ 30 .^{68}$ After his return to the United States, he gave the items to the Mariners' Museum in Newport News, Virginia, where they remain to this day. Another gudgeon sold for US\$20 and went to the Otago Museum in Dunedin, New Zealand.

The High Commission for the Western Pacific and the Colonial Office were deeply concerned about the flow of relics away from Pitcairn and into foreign or private collections and attempted to put a stop to their sale. ${ }^{69}$ In correspondence with the prime minister's office, the high commissioner and the secretary of state for the colonies argued that 'the few existing relics of H.M.S. Bounty possess a unique historical interest ... that the Islanders ought not to have allowed any of them to leave their custody' and 'that these relics should be preserved in the public interest'. ${ }^{70}$ Johnson, for his part, hardly regarded the sale of Bounty relics as exploitative. In a letter to the Colonial Office, he defended his purchase in the context of the Islanders' long-running practices of gift exchange. His expedition, after all, had brought the Pitcairners clothes, dishes and kerosene, and he had taken them to Henderson Island to collect miro wood. ${ }^{71}$

Nonetheless, the affair marked the beginning of another shift in the valuation of Bounty artefacts. In the face of a changing market and a changing relationship with outsiders, both the British Government and the Islanders made efforts to retain what they had left. The Pitcairners set up a museum in Adamstown, where tourists today can still see Bounty relics alongside hundreds of ancient Polynesian stone adzes that the Islanders have collected over the years. ${ }^{72}$ The economic incentives of the relic trade were difficult to stem, however, particularly in the face of the insatiable fascination with the Bounty story that the island's visitors so often effused. Even as late as 1973, a visitor to Pitcairn recorded that, as far as tourists were concerned, the museum merely served as 'a show window of historic merchandise that could be bought wholesale'. ${ }^{73}$ Even administrators themselves could not be trusted; Norfolk Island governor Henry Evans Maude recorded that one of his predecessors had asked the inhabitants to 'hand over any material in their possession of historical

68 JS Neill, letter, 11 June 1937, NA/ADM 1/9687.

69 AB Acheson, letter, 15 Sep 1938, NA/ADM 1/9687.

70 Sir John Balfour, letter to Downing Street, 24 May 1938, NA/ADM 1/9687.

71 Irving Johnson, letter to Ronald Lindsay, 27 July 1938, TNA/ADM 1/9687.

72 These, too, were the subject of considerable trade with outsiders. Pitcairn Island resident Nelson Dyatt sold hundreds to the Otago Museum and other institutions across the 1930s and 1940s. See the 'Dyatt Collection' in the holdings of the Otago Museum which records holdings of 743 items from Pitcairn.

73 Ian M Ball, Pitcairn: Children of Mutiny, New York, Little, Brown, 1973, p 355. 
value for safe keeping and presentation, but instead of depositing what he thus collected in the Mitchell or other library he took everything himself'. He dryly noted that 'the Islanders are therefore loath to show (and still more to lend) anything that still remains in their possession'. ${ }^{74}$

Because the supply of original Bounty pieces was hardly replenishable, while the tourist trade was inexhaustible, the mass production of new Bounty relics became all the more necessary. Pitcairn Islanders had long produced carvings, textiles and handicrafts for sale to passing ships but, during the 20th century, this expanded into a thriving home industry. The Otago Museum contains a representative set of common Pitcairn souvenirs, purchased by an archaeological expedition to the island in 1964. Locked away on a basement shelf are baskets woven from pandanus fronds and painted leaves, and miro wood carvings of sharks, turtles and the Bounty. Among the most striking items in the museum's collection is a model wheelbarrow that, like so many relics from Pitcairn, is inscribed by its maker. This one proclaims, in block letters, 'SOUVENIR FROM PITCARIN ISLAND MADE BY ELWYN CHRISTIAN'. The surname 'Christian' is often inscribed on carvings - tourists will pay a premium for an object made by a direct descendant of the famous mutineer. The inscription of a 'Bounty name' fuses the material object with both the Bounty story and its maker's status as an authentic mutineer descendant creating a hybridised and lucrative Bounty relic.

By the postwar period, the selling of Pitcairn became a well-rehearsed practice, one that continues to the present. The Islanders knew the schedule of calling ships well in advance and made radio contact with them as they approached. After a ship was sighted, the bell in the Adamstown town square was struck five times. Boxes of goods were loaded onto one or two of the island's launches before they motored through the pounding surf of Bounty Bay. At various points, there were prohibitions against women trading on the ships, but these encounters eventually became a community affair and men, women and children alike clambered out of the swaying launches and up rope ladders on the sides of visiting ships. Once on board, they set up a makeshift marketplace in no time. Douglas Thorsen described the well-ordered commotion in a 1982 account:

74 Henry Maude, 'Buffet's Diary', note in Pitcairn, Part I, A - Pitcairn Island, Box 1, Papers of Henry Evans Maude, Hocken Library, University of Adelaide. 
Every available table was spread with the miro-wood sharks, fish, birds, vases, walking sticks, turtles, miniature wheelbarrows, book-boxes, and basketware made from pandanus leaves. There were also hand-painted leaves, wall-pockets, fans, sun-bonnets, shell necklaces, coconut shell flower vases, and copies of the 'Guide to Pitcairn'. A selection of postcards and mounted sets of the postage stamps for which this island is famous. Each item had its set price and there was no bargaining; sales were brisk. ${ }^{75}$

From impromptu markets like these, souvenirs departed Pitcairn and wound their way across the globe, as they long had, but now in even greater numbers. These objects served not only as reminders of contemporary Pitcairn and its inhabitants, but of its mythologised past. Images of the Bounty and references to Fletcher Christian abound on objects manufactured by Islanders for Pitcairn's tourist trade. ${ }^{76}$ In that way these items, however recently made, serve as Bounty relics, too.

Among the most prodigious and successful purveyors of Bounty relics is the Pitcairn Islands post office. Like many microstates, Pitcairn Island found that its unique heritage and well-known story were especially easily commoditised as ephemerae for stamp collectors. The island has been issuing stamps since 1940; by the 1970s, two-thirds of all government revenue were produced from stamp sales. ${ }^{77}$ In an annual report on the island, a British administrator wrote that Pitcairn 'continues to remain solvent thanks to the philatelists of the world'. ${ }^{78}$ Stamps were artificial Bounty relics par excellence. Like other Bounty relics, they left Pitcairn in the hands of tourists or visitors and circled the globe, capturing or stimulating the sympathetic imaginations of interested outsiders oceans away. Many were cherished by collectors who had no hope of visiting Pitcairn. It was a carefully constructed cultural diplomacy; Islanders and administrators worked hard to preserve the 'authenticity' of these postagestamp relics and the images they evoked. Maude advised the government only to issue stamps on 'genuine' anniversaries and subjects, and to avoid 'fakes'. ${ }^{79}$ Accordingly, most of their images work to remind the collector of the island's romanticised past. Pitcairn stamps range from images depicting the Bounty mutiny itself to scenes from the Hollywood films

75 Douglas Thorsen, 'Only on Pitcairn', unpublished manuscript, The National Library of New Zealand, MS-Papers-3926.

76 See, for example, the island's Delectable Bounty brand of honey.

77 D Harraway, letter to Harold Smedley, 24 Mar 1980, TNA/FCO 107/217.

78 'Pitcairn: Annual Review for 1976', TNA/FCO 32/1414.

79 Henry Evans Maude, letter to Thomson Reid Cowell, 8 April 1960, Part 1, A - Pitcairn Island, Box 1, folder Pitcairn Islands Commemorative Stamp Issues, Maude Papers. 
it inspired. In my own small collection of Bounty relics is a set of postage stamps featuring Bounty relics: a set of four diamond-shaped stickers on which are illustrated the Bounty's anchor, cannon, chronometer and a copper kettle. The images on the stamps are necessarily reproductions; only one of those four relics remains on the island today. ${ }^{80}$

\section{Viewing relics from the beach}

My collection also holds another relic that, while not a Bounty relic, is a distinctly Pitcairn one. It is a small polished black shard of obsidian that feels altogether too light to be entirely natural. I found it at a place called Rope, Pitcairn's only beach. Most of the island is ringed by intimidating and dangerous cliffs but, at Rope, a perilous climb will take the visitor to a secluded, rock-bound cove. There, a broad crescent of sand is littered with boulders and, on closer inspection, small pieces of washed-up detritus in every colour, most of them pounded smooth by years of waves and surf. The islands of the Pitcairn Group are covered in all manner of ocean-born litter. A 1994 expedition's survey conducted on nearby Ducie and Oeno islands found, on average, one piece of trash for every three square metres - what the study's authors tell us is 'a comparable amount of garbage to any beach in the industrialised Western world'. ${ }^{81}$ They identified places of origin as diverse as Russia and Argentina. Most common were buoys and plastic fragments, but these ecologist-beachcombers also found plastic dolls' heads, bicycle pedals, asthma inhalers, an intact tinned meat pie and two plastic toy soldiers. I found much the same at Rope, where hermit crabs scuttle between washed-up sandals and bits of plastic pipe. Many centuries ago, the first Polynesian inhabitants of Pitcairn Island visited Rope to carve petroglyphs in its rock walls and to collect pieces of obsidian like the one I picked up from the rolling surf; today people who will never see its cliffs have marked it with an endless stream of rubbish.

Now, at the end of an essay on the material remnants of Pitcairn's postBounty encounters with the outside world, it seems an appropriate moment to make a summary accounting of the island's gifts and exchanges, of goods taken and received. Islanders and visitors alike have disseminated Pitcairn's relics around the globe. Much of the Bounty itself has long

80 www.stamps.gov.pn/BountyRelics.htm.

81 TG Benton, 'From Castaways to Throwaways: Marine Litter in the Pitcairn Islands', Biological Journal of the Linnean Society, vol 56, no 1-2, 1995, pp 415-22. 
been broken up and sold as sentimental scrap, its instruments and stores commoditised as souvenirs or sanctified as relics. The island's residents have sold innumerable Bounty carvings and Bounty stamps. They have sent letters and pressed roses. Though now deposited in private and museum collections, these objects and their biographies reveal Pitcairn to have been, like so many Pacific Islands, part of a vast network of affect-laden exchanges. Bounty relics served as mediators, connecting contemporary Pitcairn to a mythologised past, and Islanders on the edge of empire to a narrative at the heart of Britain's imperial imagination. For Pitcairners, however, the trade in Bounty relics had its limits. The island gave up its Bounty relics, piece by piece. In exchange, Pitcairn has received, in turns, finished goods, tinned and frozen meats, fascinated interest, disinterested approbation, charitable benevolence, US and New Zealand dollars, and a never-ending stream of broken plastic. 
This text is taken from The Bounty from the Beach: Cross-Cultural and Cross-Disciplinary Essays, edited by Sylvie Largeaud-Ortega, published 2018 by ANU Press, The Australian National University, Canberra, Australia. 